\title{
NILAI KARAKTER, BERPIKIR KRITIS DAN PSIKOMOTORIK ANAK USIA DINI
}

\author{
Syarip Hidayat \& Lutfi Nur \\ e-mail: lutfinur@upi.edu \\ Universitas Pendidikan Indonesia, Kampus Tasikmalaya
}

\begin{abstract}
Abstrak: Penelitian ini dilatarbelakangi oleh fakta-fakta di lapangan mengenai kondisi proses pencapaian pendidikan anak usia dini yang belum optimal. Proses pencapaian pendidikan yang dimaksud adalah nilai karakter, kemampuan berpikir kritis dan psikomotorik anak usia dini. Penelitian ini dilakukan untuk mengetahui kondisi perkembangan nilai karakter, berpikir kritis dan psikomotorik anak usia 5-6 tahun. Penelitian ini merupakan penelitian deskriptif dengan menggunakan metode survey. Subjek siswa yang dilibatkan adalah anak usia dini TK Nurul IImi dan TK Negeri Pembina yang berlokasi di Kota Tasikmalaya. Jumlah sampel dalam penelitian ini sebanyak 40 orang. Lama penelitian dilakukan selama dua bulan, yakni sejak bulan Mei sampai bulan Juli 2017. Instrumen dalam penelitian ini menggunakan observasi terstruktur dan dokumentasi. Hasil penelitian ini menunjukkan bahwa profil nilai karakter, berpikir kritis dan psikomotorik anak usia 5-6 tahun di TK Nurul IImi Kota Tasikmalaya dan TK Negeri Pembina Kota Tasikmalaya hasilnya masih belum sesuai harapan. Hal ini terlihat dari temuan di TK Nurul IImi bahwa profil nilai karakter sebesar $50,06 \%$, berpikir kritis sebesar $49,80 \%$ dan psikomotorik $50,87 \%$. Sedangkan di TK Negeri Pembina profil nilai karakter sebesar 51,22\%, berpikir kritis sebesar 50,98\% dan psikomotorik $52,17 \%$. Berdasarkan temuan tersebut, diharapkan semua kompenen di sekolah khususnya guru dapat meningkatkan kinerja dalam rangka mengoptimalkan potensi peserta didik.
\end{abstract}

Kata-kata kunci: nilai karakter, berpikir kritis, psikomotorik, anak usia dini

\section{CHARACTER VALUES, CRITICAL THINKING AND PSYCHOMOTOR EARLY CHILDHOOD}

\begin{abstract}
The research was distributed by the facts on the ground about the condition during the process of the achievement of early-childhood education that is not optimal. The process of educational achievement in question is the value of a character, critical-thinking ability and psychomotor early childhood. This research was conducted to find out the condition of the development of the value of the character, critical thinking and psychomotor children aged 5-6 years. This research uses survey method. The subjects for the students involved are early-childhood kindergarten Nurul IImi and TK Negeri Pembina. The number samples of this research in the study as many as 40 people. Long research conducted about two months. Instrument in this study using structured observation and documentation. The results from this study indicate that the profile of the value of the character, critical thinking and psychomotor children aged 5-6 years in kindergarten Nurul IImi Tasikmalaya and TK Negeri Pembina Tasikmalaya results still do not match expectations. This is apparent in the findings in kindergarten Nurul IImi that profile the value of character of $50.06 \%$, critical thinking of $49.80 \%$ and psychomotor $50.87 \%$. Whereas in TK Negeri Pembina character value profile of $51.22 \%$, critical thinking of $50.98 \%$ and psychomotor $52.17 \%$. Based on these findings, it is hoped all components in school, especially teachers can improve performance in order to optimize the potential of learners.
\end{abstract}

Keywords: character values, critical thinking, psychomotor, early-childhood

\section{PENDAHULUAN}

Anak usia dini adalah anak yang berusia kisaran 0-6 tahun (Permendikbud Nomor 137
Tahun 2014 tentang Standar PAUD). Menurut Yusuf (2012) mengatakan bahwa anak usia dini 
merupakan individu yang berada pada posisi usia perkembangan yang sangat pesat jika dibandingkan dengan masa-masa usia perkembangan lainnya. Usia tersebutlah banyak dikenal dengan istilah Golden Age atau masa usia emas (Purnama, 2016). Masa usia emas ini maksudnya adalah masa penerimaan dan pengolahan informasi yang dapat dilakukan secara cepat dan tahan lama oleh setiap individu (Santrock, 2007; Nurihsan \& Agustin, 2011; Hurlock, 2012; Yusuf, 2012). Oleh karena masa emas itu ada pada anak usia 0-6 tahun.

Pendidikan anak usia dini merupakan hal penting dan dipandang perlu untuk diketahui oleh setiap guru maupun orang tua yang mendidik anak tersebut. Secara tidak langsung dalam konteks ini tersirat tanggung jawab moral bagi guru di sekolah maupun orang tua di rumah untuk memahami nilainilai pendidikan yang harus dikembangkan oleh orang tua, guru dan lingkungan sekitarnya. Untuk memahami karakteristik anak, guru dan orang tua harus melakukan pemantauan secara khusus dan intensif terhadap segala bentuk perilaku anak yang muncul saat melakukan aktivitas di sekolah maupun di rumah. Melalui proses pemantauan secara khusus tersebut, maka akan didapat datadata berupa capaian perkembangan pendidikan anak. Data-data yang didapat dari hasil pemantauan terhadap capaian perkembangan anak tersebut dapat dijadikan sebagai tolok ukur untuk pemenuhan kebutuhan anak itu sendiri. Selain itu, menguatkan bahwa perlunya diketahui capaian perkembangan anak merupakan bahan pertimbangan bagi para pendidik untuk memenuhi kebutuhan anak dalam menghadapi pendidikan di jenjang selanjutnya (Sujiono, 2009). Hal yang perlu dikembangkan yaitu aspek kognitif, afektif dan psikomotorik.

Menurut para ahli seperti Hornby dan Parnwell (Syaodih \& Agustin, 2013) mengungkapkan bahwa karakter adalah kualitas mental atau moral, kekuatan moral, nama atau reputasi. Pendidikan memiliki peran signifikan dalam mengembangkan potensi diri manusia, dapat berdampak dinamis dalam mempengaruhi pertumbuhan fisik dan perkembangan mental, emosi sosial serta etikanya (Yusuf, 2012). Beberapa nilai karakter yang diintegrasikan melalui pendidikan karakter (Judiani, 2010), yaitu religius, jujur, toleransi, disiplin, kerja keras, kreatif, mandiri, demokratis, rasa ingin tahu, semangat kebangsaan, cinta tanah air, menghargai prestasi, bersahabat/komunikatif, cinta damai, gemar membaca, peduli lingkungan, peduli sosial dan tanggung jawab. Dalam penelitian ini karakter yang akan diungkap hanya beberapa saja antara lain adalah jujur, toleransi, disiplin, rasa ingin tahu, bersahabat/komunikatif, kerja keras.

Ranah psikomotorik merupakan bagian dari perkembangan individu yang berkaitan dengan gerak fisik berdasarkan hasil dari pengolahan antara kognisi dan afeksi yang membuahkan gerak fisik berupa perilaku. Hasil dari pemantauan terhadap capaian perkembangan psikomotorik anak tersebut dapat dijadikan sebagai tolak ukur untuk pemenuhan kebutuhan anak itu sendiri dalam menghadapi pendidikan di jenjang selanjutnya (Bloom, 1956; Rakhmat \& Solehuddin, 2006; Sujiono, 2009; Nurihsan \& Agustin, 2011). Perkembangan setiap karakteristik anak usia dini cenderung dipengaruhi oleh sentuhan-sentuhan secara fisik maupun psikis dari lingkungan hidupnya. Konteks itu dikuatkan oleh (Geldard, K. \& Geldard, 2012) bahwa lingkungan merupakan bagian terbesar dalam mempengaruhi perubahan perilaku setiap anak. Hal tersebut terjadi karena lingkungan hidup cenderung lebih menyentuh setiap aspek perkembangan anak secara dominan. Berdasarkan teori tersebut, dapat diartikan bahwa lingkungan merupakan aspek terbesar dan dapat memberikan pengaruh terhadap perkembangan anak.

Berpikir kritis sebagai suatu sikap mau berpikir secara mendalam tentang masalah-masalah dan hal-hal yang berada dalam jangkauan pengalaman seseorang, pengetahuan tentang metode-metode pemeriksaan dan penalaran yang logis dan keterampilan untuk menerapkan metode-metode tersebut (Saputri, 2014). Berpikir kritis menuntut upaya keras untuk memeriksa setiap keyakinan atau pengetahuan asumtif berdasarkan bukti pendukungnya dan kesimpulan-kesimpulan lanjutan yang diakibatkannya. Ennis (2011) menambahkan komponen tujuan berpikir kritis dalam definisinya yang dipakai secara luas yaitu, "Reasonable reflective thinking focused on deciding what to believe or do". Maksudnya bahwa berpikir kritis adalah pemikiran yang masuk akal dan reflektif yang berfokus untuk memutuskan apa yang mesti dipercaya atau dilakukan.

Lingkungan pendidikan secara formal sering dinyatakan dengan istilah sekolah. Sekolah merupakan salah satu bagian dari lingkungan hidup anak untuk mengeksplorasikan setiap 
potensi yang dimilikinya. Posisi anak usia 5-6 tahun dalam pendidikan anak usia dini umumnya sedang memperoleh pendidikan di taman kanakkanak. Oleh karena itu, istilah TK dalam hal ini dapat dikatakan sebagai sekolah bagi anak usia 5-6 tahun (Permendikbud Nomor 137 Tahun 2014). Berdasarkan pengamatan atau hasil studi lapangan, tepatnya di TK Nurul IImi Kota Tasikmalaya dan di TK Negeri Pembina Kota Tasikmalaya menyatakan bahwa terdapat beberapa hal yang dapat dinyatakan sebagai persoalan yang berkaitan dengan pencapaian proses pendidikan anak usia dini, antara lain nilai karakter, kemampuan berpikir kritis, dan keterampilan psikomotorik yang kesemuanya itu merupakan kompetensi dasar yang diharapkan dimiliki anak agar lebih siap melanjutkan pendidikan ke jenjang berikutnya serta dapat menjalani kehidupannya dengan cenderung lebih baik. Oleh karena itu, penulis akan mencoba memastikan terlebih dahulu kondisi perkembangan anak-anak di sekolah tersebut melalui sebuah penelitian. Melalui penelitian ini, penulis akan mengetahui kondisi anak serta memberikan tindakan sesuai yang dibutuhkan dalam proses pendidikan anak usia dini.

\section{METODE PENELITIAN}

Penelitian ini merupakan penelitian deskriptif dengan menggunakan metode survey. Metode survey digunakan untuk menunjukkan kepada suatu kegiatan pengamatan dan pemeriksaan dengan maksud mengumpulkan informasi tentang keberadaan sesuatu yang bersifat fisik dan/atau material (Ali, 2011). Hal ini sejalan dengan penelitian yang akan dilakukan yaitu mendapatkan informasi tentang nilai karakter, berpikir kritis dan psikomotorik anak usia dini. Subjek yang akan dilibatkan adalah anak usia 5-6 tahun. Penelitian dilaksanakan di TK Nurul IImi dan TK Negeri Pembina yang berlokasi di Kota Tasikmalaya. Lama penelitian sekitar dua bulan terhitung dari bulan Mei sampai Juli 2017.
Jumlah sampel dalam penelitian ini sebanyak 40 anak. Instrumen yang digunakan dalam penelitian ini yaitu observasi terstruktur dan dokumentasi tentang nilai karakter, berpikir kritis, dan psikomotorik. Penggunaan instrumen ini berlandas kepada (Sugiyono, 2012) beberapa instrumen yang cenderung tepat digunakan sebagai alat untuk pengambilan data. Dalam penelitian ini adalah pedoman observasi terstruktur dan dokumentasi, karena instrumen tersebut dipandang cukup dan dapat memberikan kontribusi dalam mendapatkan data-data untuk melihat perkembangan nilai karakter, berpikir kritis dan psikomotorik anak usia 5-6 tahun.

\section{HASIL DAN PEMBAHASAN}

Hasil

Penelitian ini memberikan gambaran mengenai suatu fenomena tertentu yaitu nilai karakter, kemampuan berpikir kritis, dan keterampilan psikomotorik pada anak usia 5-6 tahun. Berdasarkan pegambilan data yang telah dilakukan, diperoleh data nilai karakter, kemampuan berpikir kritis, dan keterampilan psikomotorik anak usia 5-6 tahun di TK Nurul IImi Kota Tasikmalaya dan TK Negeri Pembina Kota Tasikmalaya.

Deskripsi data TK Nurul IImi Kota Tasikmalaya

Sampel dalam penelitian ini adalah kelompok siswa TK Nurul IImi Kota Tasikmalaya. Data kelompok siswa TK Nurul IImi Kota Tasikmalaya seperti terlihat pada Tabel 1 dan Tabel 2.
Tabel 1

Profil Kelompok Siswa TK Nurul IImi

\begin{tabular}{cccc}
\hline No & Berpikir kritis & Psikomotor & Karakter \\
\hline 1 & 57 & 37 & 53 \\
2 & 49 & 36 & 42 \\
3 & 50 & 37 & 48 \\
4 & 51 & 35 & 47 \\
5 & 53 & 37 & 46 \\
6 & 50 & 36 & 51 \\
7 & 47 & 35 & 46 \\
8 & 46 & 35 & 43 \\
9 & 50 & 32 & 38 \\
10 & 48 & 30 & 39 \\
11 & 53 & 32 & 40 \\
\hline
\end{tabular}




\begin{tabular}{cccc}
\hline No & Berpikir kritis & Psikomotor & Karakter \\
\hline 12 & 50 & 40 & 50 \\
13 & 56 & 40 & 48 \\
14 & 52 & 36 & 46 \\
15 & 51 & 35 & 45 \\
16 & 53 & 36 & 45 \\
17 & 50 & 32 & 44 \\
18 & 48 & 33 & 42 \\
19 & 51 & 34 & 45 \\
20 & 51 & 34 & 43 \\
\hline Jumlah & 1016 & 702 & 901 \\
Rata-rata & 50,8 & 35,1 & 45,05 \\
Sd & 2,73 & 2,55 & 3,89 \\
\hline
\end{tabular}

Tabel 1 menunjukkan data berpikir kritis, psikomotor dan karakter anak usia 5-6 tahun di TK Nurul IImi Kota Tasikmalaya. Profil berpikir kritis diperoleh jumlah skor sebesar 1016, rata-rata 50,8 dan simpangan baku 2,73. Selanjutnya untuk psikomotor diperoleh jumlah skor sebesar 702, rata-rata sebesar 35,1 dengan simpangan baku sebesar 2,55, sedangkan untuk karakter diperoleh jumlah skor sebesar 901 dengan rata-rata 45,05 dan simpangan baku sebesar 3,89.

Untuk memberikan gambaran lebih lanjut, berikut ditampilkan data berpikir kritis, psikomotor dan karakter anak usia 5-6 tahun di TK Nurul IImi Kota Tasikmalaya dalam bentuk grafik seperti terlihat pada Gambar 1.

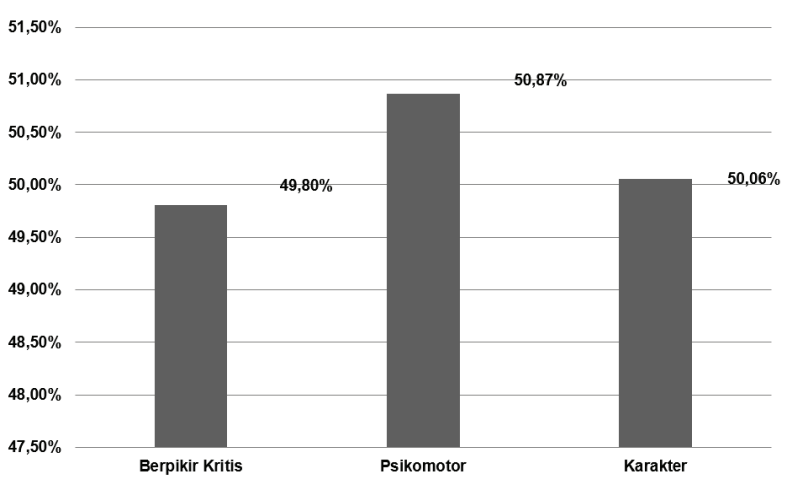

Gambar 1. Profil kelompok siswa TK Nurul IImi

Gambar 1 menunjukkan data berpikir kritis, psikomotor dan karakter anak usia 5-6 tahun di TK Nurul IImi Kota Tasikmalaya berdasarkan presentase jumlah perolehan skor dari skor maksimal. Persentase berpikir kritis sebesar $49,80 \%$, psikomotor sebesar $50,87 \%$ dan untuk persentase karakter sebesar 50,06\%.

Hasil pengambilan data awal menunjukkan perolehan skor berpikir kritis, psikomotor, dan karakter anak usia 5-6 tahun di TK Nurul IImi Kota Tasikmalaya. Berdasarkan hasil penelitian diperoleh profil data berpikir kritis dengan jumlah skor sebesar 1016, rata-rata 50,8, simpangan baku 2,73 dengan persentase sebesar $49,80 \%$. Psikomotor dengan jumlah skor sebesar 702 , rata-rata sebesar 35,1 , simpangan baku sebesar 2,55 dengan persentase sebesar $50,87 \%$, sedangkan untuk karakter diperoleh jumlah skor sebesar 901 dengan rata-rata 45,05, simpangan baku sebesar 3,89 dan persentase sebesar $50,06 \%$. Perolehan skor tertinggi dari ketiga variabel pada TK Nurul IImi Kota Tasikmalaya hanya memperoleh persentase sebesar $50,87 \%$, yaitu dari variabel psikomotor. Hal ini mengindikasikan secara keseluruhan ketiga variabel masih tidak sesuai dengan harapan. Mengingat pentingnya optimalisasi tumbuh kembang anak usia dini hal ini perlu penanganan lebih lanjut.

Masa perkembangan anak usia dini merupakan masa perkembangan "The golden age", sehingga diperlukan metode pendidikan yang tepat dalam upaya mengoptimalkan perkembangan potensinya. Pada masa ini optimalisasi perkembangan anak dalam aspek seperti berpikir kritis, keterampilan psikomotorik dan karakter anak usia 5-6 tahun sangatlah penting. Perolehan data menunjukkan bahwa ketiga aspek atau variabel tersebut masih jauh dari harapan, sedangkan pendidikan karakter, kognitif dan psikomotorik seharusnya diterapkan sejak anak usia dini, karena sangat menentukan kemampuan anak dalam mengembangkan potensinya. Lebih lanjut lagi merupakan bekal penting dalam mempersiapkan anak usia dini untuk menyongsong masa depan yang penuh dengan tantangan, baik secara akademis maupun dalam kehidupan berbangsa dan bernegara (Sudaryanti, 2012). Oleh karena itu, perlu dilakukan pemecahan masalah secara cepat dan tepat untuk mencegah berbagai kerugian/kehancuran dalam hal ini. Untuk menangani hal ini perlu digunakan atau dirancang suatu program yang dapat diterapkan pada anak usia dini, khususnya usia 5-6 tahun.

\section{Deskripsi data TK Negeri Pembina Kota Tasikmalaya}

Sampel dalam penelitian ini adalah kelompok siswa TK Negeri Pembina Kota Tasikmalaya. Data kelompok siswa TK Negeri Pembina Kota 
Tasikmalaya seperti terlihat pada Tabel 2 .

Tabel 2

Profil Kelompok Siswa TK Negeri Pembina

\begin{tabular}{|c|c|c|c|}
\hline No & Berpikir kritis & Psikomotor & Karakter \\
\hline 1 & 59 & 41 & 53 \\
\hline 2 & 50 & 35 & 42 \\
\hline 3 & 54 & 36 & 48 \\
\hline 4 & 53 & 35 & 47 \\
\hline 5 & 54 & 39 & 46 \\
\hline 6 & 56 & 39 & 51 \\
\hline 7 & 54 & 37 & 46 \\
\hline 8 & 48 & 35 & 43 \\
\hline 9 & 50 & 31 & 44 \\
\hline 10 & 49 & 29 & 46 \\
\hline 11 & 46 & 38 & 43 \\
\hline 12 & 57 & 41 & 52 \\
\hline 13 & 56 & 39 & 45 \\
\hline 14 & 52 & 36 & 48 \\
\hline 15 & 50 & 34 & 48 \\
\hline 16 & 52 & 35 & 49 \\
\hline 17 & 50 & 36 & 43 \\
\hline 18 & 48 & 34 & 40 \\
\hline 19 & 52 & 37 & 45 \\
\hline 20 & 50 & 33 & 43 \\
\hline Jumlah & 1040 & 720 & 922 \\
\hline Rata-rata & 52 & 36 & 46,1 \\
\hline $\mathrm{Sd}$ & 3,37 & 3,06 & 3,45 \\
\hline
\end{tabular}

Tabel 2 menunjukkan data berpikir kritis, psikomotor dan karakter anak usia 5-6 tahun di TK Negeri Pembina Kota Tasikmalaya. Profil berpikir kritis diperoleh jumlah skor sebesar 1040, dengan rata-rata 52, dan simpangan baku 3,37. Sementara itu, psikomotor diperoleh jumlah skor sebesar 720 , rata-rata sebesar 36 dan simpangan baku sebesar 3,06, sedangkan untuk karakter diperoleh jumlah skor sebesar 922 dengan rata-rata 46,1 dan simpangan baku sebesar 3,45. Selain menggunakan tabel di atas, gambaran profil data juga disajikan dalam bentuk grafik, seperti pada Gambar 2 .

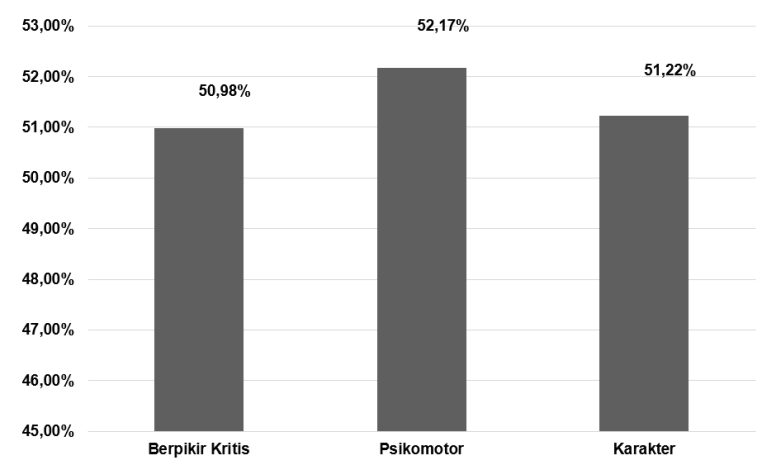

Gambar 2. Kelompok siswa TK Nurul IImi
Gambar 2 menggambarkan data berdasarkan presentase dari skor maksimal. Variabel berpikir kritis memperoleh persentase sebesar 50,98\% dari skor maksimal, psikomotor memperoleh persentase sebesar $52,17 \%$ sedangkan untuk variabel karakter diperoleh persentase sebesar $51,22 \%$ dari skor maksimal. Dari ketiga variabel, diketahui bahwa variabel psikomotor memperoleh presentase paling tinggi, sehingga untuk memberikan gambaran lebih lanjut pada pembahasan selanjutnya maka diberikan gambaran perbandingan profil berpikir kritis, psikomotor dan karakter anak usia 5-6 tahun di TK Nurul IImi Kota Tasikmalaya dan TK Negeri Pembina Kota Tasikmalaya.

Pengambilan data awal menunjukkan profil data berpikir kritis, kemampuan psikomotor dan nilai karakter anak usia 5-6 tahun di TK Negeri Pembina Kota Tasikmalaya. Data tersebut menunjukkan bahwa variabel kemampuan berpikir kritis memperoleh jumlah skor sebesar 1040; ratarata 52; simpangan baku 3,37; dan persentase sebesar 50,98\%. Psikomotor dengan jumlah skor sebesar 720; rata-rata sebesar 36; simpangan baku 3,06 ; dan persentase sebesar $52,17 \%$. Sementara itu untuk nilai karakter diperoleh jumlah skor sebesar 922 dengan rata-rata 46,1; simpangan baku sebesar 3,45 ; dan persentase sebesar $51,22 \%$. Perolehan skor tertinggi dari ketiga variabel diperoleh variabel kemampuan psikomotor dengan persentase sebesar $52,17 \%$. Seperti pada kelompok siswa TK Nurul IImi Kota Tasikmalaya juga masih memperoleh nilai di bawah harapan. Dengan demikian, dapat diartikan bahwa perkembangan anak usia dini terkait variabel berpikir kritis, kemampuan psikomotor, dan nilai karakter pada kelompok siswa TK Negeri Pembina masih belum optimal.

Menurut Yusuf (2012), mengatakan bahwa anak usia dini merupakan individu yang berada pada posisi usia perkembangan yang sangat pesat jika dibandingkan dengan masa-masa usia perkembangan lainnya. Usia tersebut dikenal dengan istilah Golden Age atau masa usia emas. Masa usia emas merupakan masa penerimaan dan pengolahan informasi yang dapat dilakukan secara cepat dan tahan lama oleh setiap individu (Santrock, 2007); (Nurihsan \& Agustin, 2011); (Hurlock, 2012); dan (Yusuf, 2012). Masa emas berada pada anak usia 0-6 tahun, oleh karena itu, dalam permasalahan ini penting untuk menciptakan suatu program yang sesuai dengan masa perkembangan anak usia dini. 
Perkembangan setiap karakteristik anak usia dini cenderung dipengaruhi oleh sentuhan-sentuhan secara fisik maupun psikis dari lingkungan hidupnya. Konteks itu dikuatkan oleh Geldard, K. \& Geldard (2012) bahwa lingkungan merupakan bagian terbesar dalam mempengaruhi perubahan perilaku setiap anak. Terlebih lagi pada variabel kemampuan psikomotorik yang juga tidak kalah penting dari aspek lainnya.

Hurlock (2012) mengemukakan salah satu pengaruh motorik individu adalah "Peningkatan potensi perkembangan psikomotorik sangat penting bagi perkembangan self concept (kepribadian anak)". Perkembangan psikomotorik anak usia dini cenderung mendapat sentuhan dari lingkungan hidupnya. Lingkungan merupakan bagian terbesar dari perubahan perilaku hidup setiap anak, karena lingkungan hidup cenderung menyentuh secara dominan terhadap setiap aspek perkembagan anak (Geldard, K. \& Geldard, 2012). Oleh karena itu, aspek yang paling besar mempengaruhi psikomotorik anak adalah lingkungan. Selain dari pada itu untuk mengoptimalkan perkembangan anak sangatlah penting untuk merancang suatu program yang dapat disesuaikan dengan lingkungan anak usia dini guna mendukung optimalisasi perkembangannya.

\section{Pembahasan}

Hasil penelitian menunjukkan bahwa kemampuan berpikir kritis, kemampuan psikomotor dan nilai karakter anak usia 5-6 tahun di TK Nurul IImi Kota Tasikmalaya dan TK Negeri Pembina Kota Tasikmalaya masih rendah. Dapat dikatakan perkembangan anak usia dini khususnya pada ketiga variabel penelitian masih belum optimal. Mengingat pentingnya perkembangan aspekaspek tersebut pada anak usia 5-6 tahun, hal ini harus mendapat perhatian lebih. Salah satu teori perkembangan individu yang diuraikan oleh Rakhmat, Budiman, \& Herawati (2008) yaitu teori ketiga menyatakan bahwa perkembangan seseorang dipengaruhi oleh dua faktor, yaitu faktor bawaan dan faktor lingkungan. Potensi yang dimiliki anak sejak lahir akan berkembang ketika dibesarkan dalam lingkungan yang mendukung. Sebaliknya, bagaimanapun besarnya potensi seseorang, tidak akan berarti apa-apa bila tidak dikembangkan dalam lingkungan yang baik. Van de Waal \& Henriette (1993) mengatakan tentang sebuah penelitian yang dilakukan oleh The Twin Study menunjukkan bahwa $90 \%$ kondisi fisik ditentukan oleh faktor hereditas, sementara keterampilan fisik diperoleh dari kondisi lingkungan keluarga itu sendiri, maka untuk mengoptimalkan perkembangan anak usia dini diperlukan suatu aktivitas yang sesuai dengan lingkungannya. Selain itu, aspek yang paling besar mempengaruhi psikomotorik anak adalah lingkungan.

Ardiyansyah (2012) mengemukakan beberapa pengaruh motorik individu, diantaranya (a) anak dapat menghibur dirinya dan memperoleh perasaan senang, seperti anak merasa senang memiliki keterampilan memainkan boneka, melempar bola dan memainkan alat-alat mainan; (b) anak dapat beranjak dari kondisi tidak berdaya pada bulanbulan pertama dalam kehidupanya kepada kondisi yang independen; (c) anak dapat menyesuaikan dangan lingkungan sekolah. Pada masa pra sekolah atau pada masa awal sekolah dasar, anak sudah dapat dilatih menulis, menggambar melukis dan baris berbaris; (d) melalui peningkatan potensi perkembangan psikomotorik yang normal memungkinkan anak dapat bermain dan bergaul dengan teman sebayanya, sedangkan yang tidak normal akan menghambat dalam bergaul dengan teman sebayanya, bahkan dia akan terkucilkan atau menjadi anak yang terpinggirkan; dan (e) peningkatan potensi perkembangan psikomotorik sangat penting bagi perkembangan self concept (kepribadian anak).

Berdasarkan temuan secara praktis dari hasil penelitian dan didukung oleh beberapa penemuan hasil penelitian sebelumnya, dapat disimpulkan bahwa kondisi perkembangan nilai karakter, berpikir kritis dan psikomotorik anak usia 5-6 tahun di TK Nurul IImi dan TK Negeri Pembina masih dalam kategori belum sesuai harapan.

\section{PENUTUP}

\section{Kesimpulan}

Hasil penelitian menunjukkan bahwa profil nilai karakter, berpikir kritis dan psikomotorik anak usia 5-6 tahun di TK Nurul IImi Kota Tasikmalaya dan
TK Negeri Pembina Kota Tasikmalaya masih belum sesuai harapan. Hal ini terlihat dari temuan di TK Nurul IImi bahwa profil nilai karakter sebesar 50,06\%; berpikir kritis sebesar 49,80\%; dan psikomotorik 
50,87\%; sedangkan di TK Negeri Pembina diperoleh profil nilai karakter sebesar $51,22 \%$; berpikir kritis sebesar 50,98\%; dan psikomotorik sebesar $52,17 \%$. Saran

Berdasarkan hasil penelitian dan pembahasan, saran yang dapat diajukan adalah mencari alternatif solusi dengan upaya meningkatkan nilai karakter, kemampuan berpikir kritis, dan psikomotorik anak usia dini yang terlihat masih belum optimal. Adapun hal-hal yang perlu dilakukan antara lain meningkatkan kompetensi guru dengan cara menerapkan model pembelajaran yang efektif dan meningkatkan fasilitas yang ada di sekolah dalam rangka meningkatkan perkembangan potensi peserta didik. Selain itu, bagi peneliti lanjutan perlu diperluas skala subjek yang menjadi sampel dan memungkinkan untuk mencoba beberapa alternatif model pembelajaran untuk mengembangkan potensi anak usia dini.

\section{DAFTAR PUSTAKA}

Ali, M. (2011). Memahami riset perilaku dan sosial. Jakarta: Bumi Aksara.

Ardiyansyah, E.C.A., (2012). Pengaruh permainan tradisional terhadap peningkatan keterampilan sosial anak prasekolah. Disertasi. UIN Sunan Ampel Surabaya.

Bloom, B. S. dkk. (1956). Taxonomy of educational objectives. New York: David McKay.

Ennis, R.H. (2011). The nature of critical thinking: An outline of critical thinking dispositions and disabilities. Makalah dipresentasikan pada Sixth International Conference on Thinking at MIT Cambridge, Mei 2011. http://faculty. education.illinois.edu/rhennis/documents/ TheNatureofCriticalThinking_51711_000.pdf

Geldard, K. \& Gerald, D. (2012). Konseling anakanak. Jakarta: Indeks.

Hurlock, E. B. (2012). Psikologi perkembangan. Jakarta: Erlangga.

Judiani, S. (2010). Implementasi pendidikan karakter di sekolah dasar melalui penguatan pelaksanaan kurikulum. Jurnal Pendidikan dan Kebudayaan, 16(9), 280-289. doi: 10.24832\%2Fjpnk.v16i9.519

Nurihsan, A. J. \& Agustin, M. (2011). Dinamika perkembangan anak dan remaja. Bandung: Refika Aditama.

Permendikbud no. 137 tahun 2014 Tentang Standar Nasional Pendidikan Anak Usia Dini.

Purnama, S. (2016). Materi-materi pilihan dalam parenting education menurut Munif Chatib. Jurnal IImiah Tumbuh Kembang Anak Usia Dini, 1(1), 1-16. http://ejournal.uin-suka. ac.id/tarbiyah/index.php/goldenage/article/ view/1245

Rakhmat, C. \& Solehuddin, M. (2006). Pengukuran dan penilaian hasil belajar. Bandung: Andira.

Rakhmat, C., Budiman, N., \& Herawati, N. I. (2008). Psikologi pendidikan. Bandung: UPI Press.

Santrock, J. W. (2007). Perkembangan anak. Jakarta: Erlangga.

Saputri, N.I. (2014). Upaya meningkatkan kemampuan berpikir kritis siswa kelas $V$ melalui inkuiri terbimbing. Skripsi. Universitas Negeri Yogyakarta.

Sudaryanti. (2012). Pentingnya pendidikan karakter anak usia dini. Jurnal Pendidikan Anak, 1(1), 11-20. https://journal.uny.ac.id/index.php/jpa/ article/view/2902

Sugiyono. (2012). Metode penelitian kualitatif, kuantitatif, dan R\&D. Bandung: Alfabeta.

Sujiono, Y. N. (2009). Konsep dasar pendidikan anak usia dini. Jakarta: Indeks.

Syaodih, E. dan Agustin, M. (2013). Penelitian bidang keilmuan: Penerapan permainan tradisional "Kaulinan Barudak" untuk mengembangkan nilai karakter anak. Bandung: UPI.

Van de Waal, D. \& Henriette, A. (1993). Environmental factors influencing growth and pubertal development environmental factors influencing growth and pubertal development. Amsterdam: Department of Pediatrics, Free University Hospital.

Yusuf. LN., S. (2012). Psikologi perkembangan anak \& remaja. Bandung: Remaja Rosdakarya. 